\title{
ANALIZA WSKAZAŃ DO PORODÓW OPERACYJNYCH W LATACH 2016-2018 W SZPITALU ŚW. RODZINY W POZNANIU
}

\author{
ANALYSIS OF INDICATIONS FOR CESAREAN SECTION AND INSTRUMENTAL VAGINAL DELIVERY \\ BETWEEN 2016-2018 IN THE ST. FAMILY HOSPITAL IN POZNAŃ
}

Magdalena Szumska, Martyna Kozłowska-Wytyk, Tomasz Olejniczak

Szpital Św. Rodziny w Poznaniu

DOI: https://doi.org/10.20883/ppnoz.2019.30

\section{STRESZCZENIE}

W przedstawionym artykule przeanalizowano udział cięć cesarskich i porodów operacyjnych drogą pochwową w ogólnej liczbie porodów w Szpitalu św. Rodziny w Poznaniu w latach 2016-2018. Porównano na przestrzeni lat wskazania zarówno do porodów operacyjnych drogą pochwową, jak i cięć cesarskich. Najczęstszym wskazaniem do ukończenia porodu zabiegowo okazały się objawy zagrożenia życia płodu w II okresie porodu, niezależnie od zastosowanej metody (kleszcze vs. wyciągacz próżniowy), osiągając od 90 do 95\% ogółu porodów operacyjnych drogą pochwową. Udział cięć cesarskich w ogólnej liczbie porodów w analizowanym okresie wzrósł od 30,1\% do 34,0\%. Najczęstszymi wskazaniami do wykonania cięcia cesarskiego były objawy zagrożenia życia płodu i brak postępu porodu. Uzyskane dane porównano z wynikami analiz przeprowadzonych w innych szpitalach ginekologiczno-położniczych o innym poziomie referencyjności oraz z danymi opublikowanymi przez ACOG [18].

Słowa kluczowe: cięcie cesarskie, poród operacyjny drogą pochwową, analiza wskazań, kleszcze położnicze, wyciągacz próżniowy, wskazania do cięcia cesarskiego.

\section{ABSTRACT}

In the presented article, the share of cesarean sections and instrumental vaginal deliveries was analyzed as far as the total number of deliveries between 2016-2018 in the St. Family Hospital is concerned. Indications for both vaginal delivery and cesarean section were compared over the years. The most common indications for the operative way of termination of the spontaneous labor were symptoms of fetal distress during the second period of labor (regardless of weather forceps or vacuum extractor were used) reaching about 90 and $95 \%$ of the total numer of instrumental vaginal deliveries. The part of caesarean sections in the total number of deliveries according to the analyzed period of time increased from $30.1 \%$ to $34.0 \%$. The most common indications for caesarean sections were symptoms of fetal distress and failure to progress in labour. The obtained data was compared to the results of analysis performed in other gynecology and obstetrics hospitals (presenting different reference level) and to data published by ACOG [18].

Keywords: caesarean section, vaginal delivery, obstetric forceps, vacuum extractor, indications for caesarean section.

\section{Wstęp}

Cięcie cesarskie jest najczęstszą wykonywaną w położnictwie operacją [1]. Umożliwia zakończenie ciąży i porodu w sposób bezpieczny dla matki i dziecka, nie jest jednak operacją całkowicie pozbawioną powikłań. Należy zwrócić uwagę, iż śmiertelność kobiet po cięciu cesarskim jest 3-4 razy większa niż po porodzie drogami natury. [2] Literatura jasno określa wskazania do cięcia cesarskiego i do operacji położniczych drogą pochwową. Najczęściej wymieniane z nich to objawy zagrożenia życia płodu oraz niepostępujący poród [3, 4, 5, 6]. Podręcznikowo wskazania do cięcia cesarskiego dzielimy na wskazania elektywne, pilne, naglące i nagłe (natychmiastowe). W sytuacji kiedy na długo przed porodem znane są czynniki uniemożliwijące ciężarnej bezpieczne odbycie porodu drogą pochwową planowane jest zakończenie ciąży na drodze elektywnego cięcia cesarskiego $[3,5,6]$. W ten sposób traktowane będą pacjentki ze wskazaniami ze specjalizacji pozapołożniczych (neurologia, okulistyka itd.), jak również pacjentki, u których stwierdzono niekorzystne uwarunkowania położnicze - w tym cienką bliznę macicy po cesarskim cięciu czy nieprawidłowe położenie płodu. Za wskazania pilne uznajemy czynniki, które potencjalnie zagrażają życiu i zdrowiu matki oraz płodu, ale nie stwarzają bezpośredniego zagrożenia życia $w$ danym momencie. Istnieją przesłanki jednak, że pogorszenie może wystapić w każdej chwili, a dalsze oczekiwanie i ewentualny postęp porodu może pogorszyć sytuację położniczą i warunki do wykonania cięcia. Przykładem takiego wskazania jest brak postępu porodu wynikający z nieprawidłowego ułożenia główki czy dystocja szyjkowa. Wskazania naglące 
to zaburzenia potencjalnie zagrażające życiu i zdrowiu matki oraz płodu, które powtarzając się w krótkich odstępach czasu mogą stworzyć bezpośrednie zagrożenie życia dla matki lub płodu w każdej chwili. To sytuacje, w których poród należy ukończyć jak najszybciej. Zaliczamy do nich powtarzające się epizody bradykardii czy wystepowanie deceleracji późnych lub zmiennych, przy nieefektywnej czynności skurczowej macicy. W przypadku zaburzeń u matki lub płodu występujących w sposób ciągły, bezpośrednio zagrażających ich życiu i zdrowiu mówimy o wskazaniach nagłych. Do najczęstszych przyczyn tych zaburzeń zaliczamy przedwczesne oddzielenie łożyska, wypadnięcie pępowiny czy zagrażającą rzucawkę. Cięcie cesarskie powinno być wykonane w ciągu minut, bez oczekiwania na wyniki badań laboratoryjnych, a nawet bez oznaczenia grupy krwi $[4,5,6]$.

Od wielu lat środowisko lekarskie i organizacje związane ze służbą zdrowia zwracają uwagę na rosnący odsetek ciąż zakończonych cięciem cesarskim. W 2015 roku ówczesny minister zdrowia Konstanty Radziwiłł mówił - liczbie $43 \%$ ciąż zakończonych cięciem w Polsce. W związku z tym powołano zespół, który w tym samym roku opracował nowe Standardy Opieki Okołoporodowej, mające na celu zmniejszenie liczby cięć cesarskich w kraju [7]. W następnych latach odsetek ciąż zakończonych cięciem wynosił kolejno 45,8\% w 2016 i 43,9\% w 2017 [8]. Zgodnie z rekomendacjami WHO udział porodów zakończonych drogą brzuszną z uzasadnionych wskazań, niezależnie od regionu geograficznego, nie powinien przekraczać 15\% [9]. Najniższy odsetek cięć cesarskich mają kraje Europy północnej: Finlandia $(16,4 \%)$, Norwegia $(16,5 \%)$ czy Islandia $(16,1 \%)[8]$.

Alternatywą do cięć cesarskich, związanych głównie z nieprawidłowościami w II okresie porodu, umożliwiającą zmniejszenie ogólnej liczby cięć cesarskich są porody operacyjne drogą pochwową za pomocą kleszczy wyjściowych lub wyciągacza próżniowego. Wymagają one jednak spełnienia odpowiednich kryteriów w ocenie sytuacji położniczej oraz niewątpliwie doświadczonej ręki położnika, umożliwiającej bezpieczne przeprowadzenie procedury [3].

Należy również zwrócić uwagę na fakt, iż odsetek cięć cesarskich w ogólnej liczbie porodów jest ściśle związany ze stopniem referencyjności szpitala położniczego. I poziom opieki perinatalnej obejmuje opiekę nad fizjologicznie przebiegającą ciążą, porodem, połogiem i zdrowym noworodkiem. II poziom obejmuje również opiekę nad patologią ciąży średniego stopnia, podczas gdy III poziom obejmuje opiekę nad najcięższą patologią ciąży. [10] W związku z powyższym można spodziewać się wyż- szych odsetków cięć cesarskich w przypadku ośrodków o wyższych stopniach referencyjności.

\section{Cel}

W niniejszej pracy przeanalizowano statystycznie wskazania do cięć cesarskich oraz porodów operacyjnych drogą pochwową w latach 2016-2018 w Szpitalu Św. Rodziny w Poznaniu. Szpital ten jest ośrodkiem posiadającym ॥ poziom referencyjności opieki perinatalnej tj. obejmuje opiekę nad fizjologicznie przebiegającą ciążą, porodem i połogiem oraz zdrowym noworodkiem, a także nad patologią ciąży średniego stopnia [10].

\section{Materiał i metody}

Do analizy wykorzystano dane z książek porodowych oraz statystyki szpitalne z lat 2016-2018. Pacjentki analizowano w dwóch grupach. W pierwszej znalazły się ciąże zakończone cięciem cesarskim, zaś w drugiej porody ukończone operacją kleszczową i wyciągaczem próżniowym.

\section{Wyniki}

Analiza wskazań do porodów operacyjnych drogą pochwową z okresu 2016-2018 wykazała, że niezależnie od zastosowanej metody (kleszcze vs. wyciągacz próżniowy), najczęstszym wskazaniem są objawy zagrożenia życia płodu w II okresie porodu. Ich odsetek waha się między 90 a 95\% ogółu porodów operacyjnych drogą pochwową. Spośród pozostałych wskazań odnotowano również przedłużający się II okres porodu, w tym związany z nieskutecznym parciem, nieprawidłowym zwrotem główki płodu, brakiem współpracy lub zmęczeniem rodzącej (Rycina 1).

Odsetek ciąż zakończonych drogą brzuszną w ostatnim trzyleciu powoli rośnie. Z analizowanych danych wynika, że spośród wskazań do cięć cesarskich zdecydowaną większość stanowią objawy zagrożenia życia płodu (19\%23\%) i brak postępu porodu (15\%-19\%). Pozostałe wskazania kształtują się, jak przedstwiono na wykresie ponizzej (Rycina 2).

W kategorii objawy zagrożenia życia płodu ujęto zarówno porody zakończone cięciem cesarskim z powodu nagłego pogorszenia się zapisu KTG śródporodowego jaki i rozpoczynających się objawów zagrożenia życia płodu np. w przebiegu IUGR. W kategorii brak postępu porodu ujęto jego nieprawidłowy przebieg w czesie I i II okresu porodu oraz, celem uproszczenia analizy, sytuacje związane z niewspółmiernością porodową lub nieprawidłowym wstawianiem się części przodującej. W niniejszej analizie do nagłych sytuacji położniczych wliczono: przedwczesne 


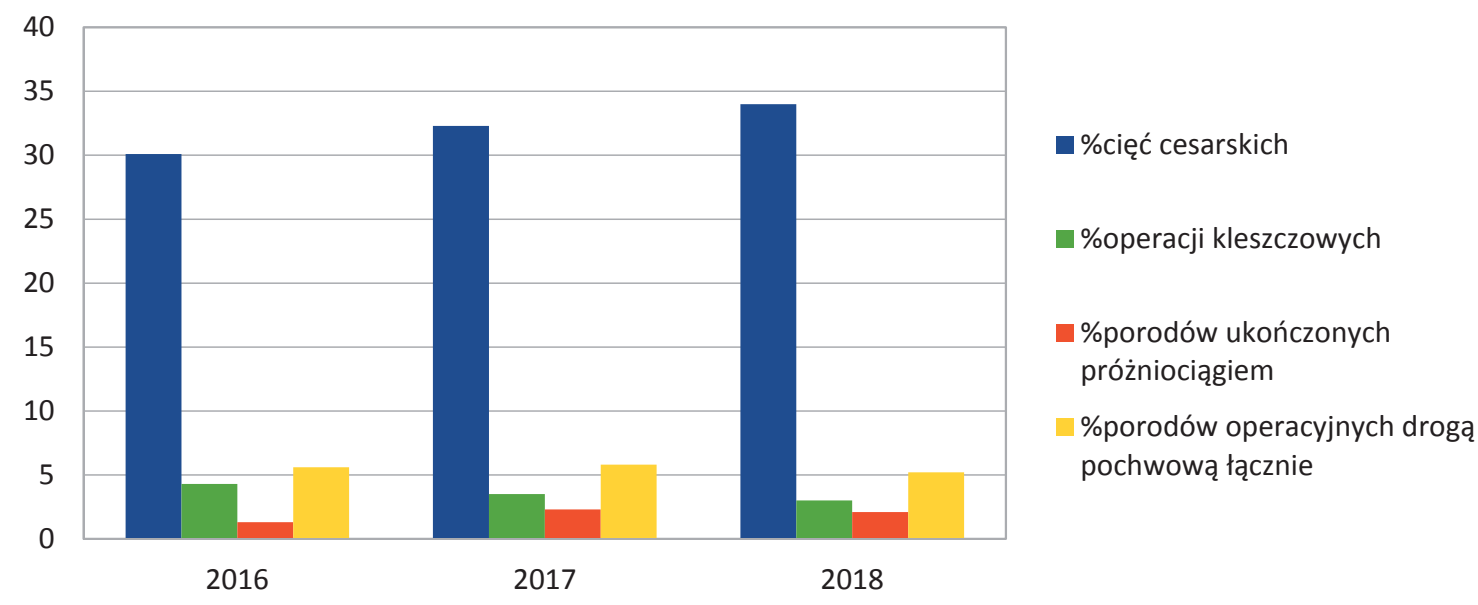

Rycina 1. Procentowy udział porodów operacyjnych w ogólnej liczbie porodów

tan po CC - brak akceptacji próby PSN

Wsk. Pozapołożnicze

nagłe sytuacje położnicze

Makrosomia / przewidywana duża masa płodu

ciąża wielpłodowa

położenie inne niż główkowe

brak postępu porodu i nieprawidłowy...

objawy zgrożenia życia płodu

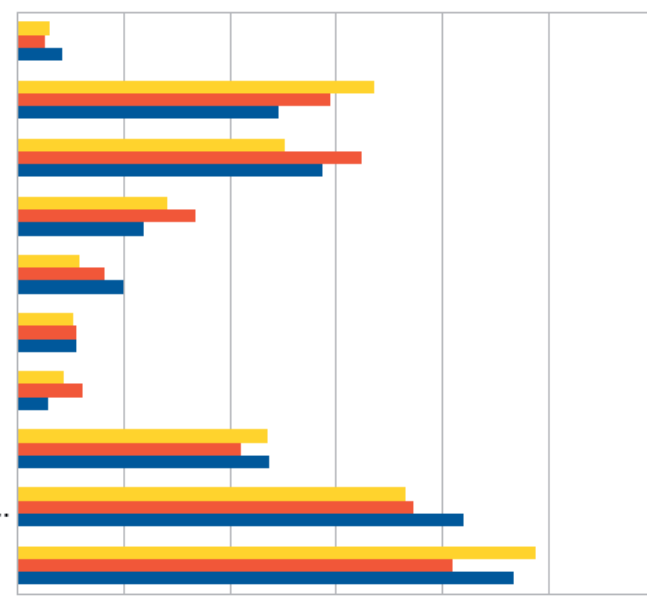

0

0,05

0,1

0,15

$0,2 \quad 0,25 \quad 0,3$

2018

- 2017

• 2016

Rycina 2. Udział wskazań do cięć cesarskich w latach 2016-2018

oddzielenie łożyska, wypadnięcie pępowiny, ciężki stan przedrzucawkowy i zagrażającą rzucawkę, HELLP, ciężką cholestazę i inne. We wskazaniach pozapołożniczych znalazły się wskazania psychiatryczne, okulistyczne, ortopedyczne, neurologiczne, kardiologiczne, chirurgiczne - zestawienie przedstawiono na rycinie 3.
W ogólnej liczbie porodów drogą cięcia cesarskiego wykonywanych po uprzednim cięciu cesarskim zdecydowaną większość wskazań stanowią cięcia u pacjentek niewyrażających zgody na próbę porodu drogami natury. Do pozostałych ujętych w analizie należą - jak w tabeli 1. 


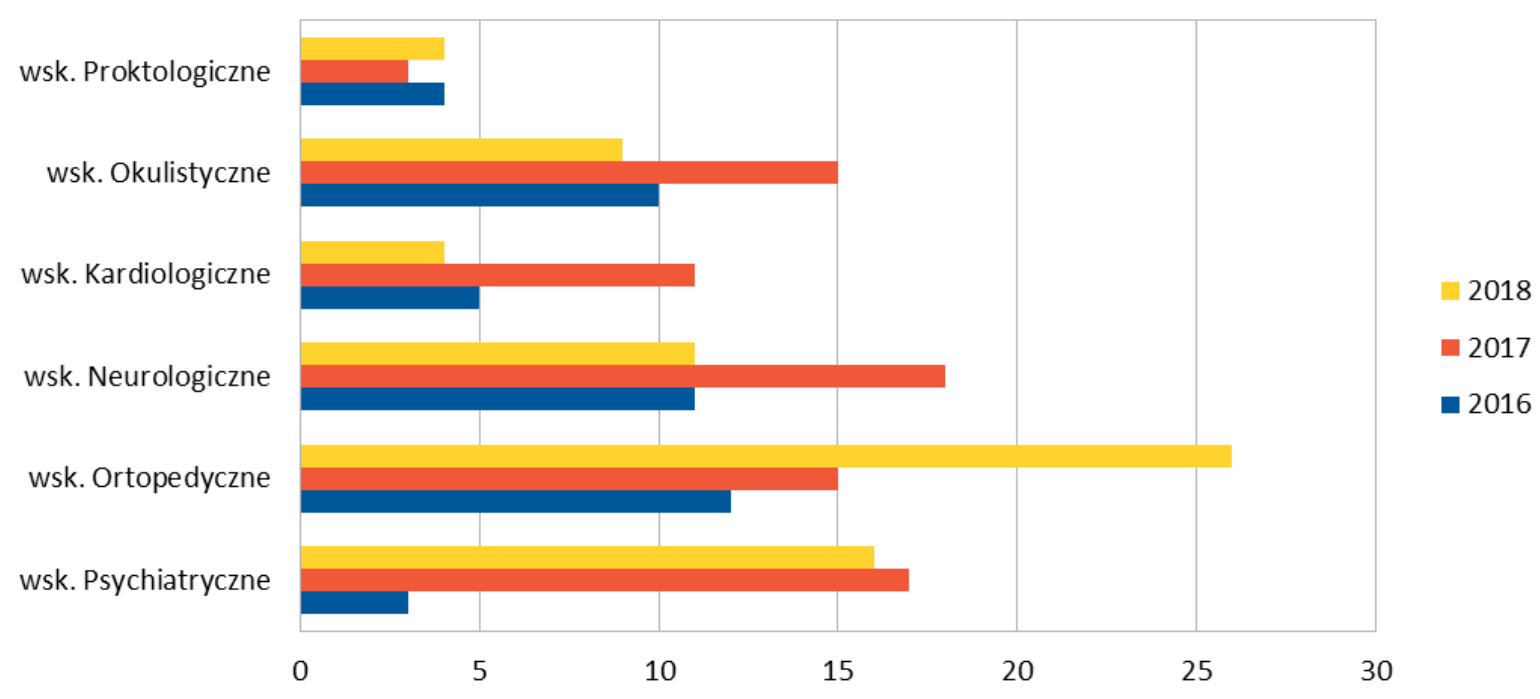

Rycina 3. Udział wskazań do cięć cesarskich ze specjalizacji pozapołożniczych

Tabela 1. Rozkład procentowy wskazań do powtórnego cięcia cesarskiego w latach 2016-2018

\begin{tabular}{|l|r|r|r|r|r|r|}
\hline & \multicolumn{2}{|c}{$\mathbf{2 0 1 6}$} & $\mathbf{2 0 1 7}$ & \multicolumn{2}{|c|}{$\mathbf{2 0 1 8}$} \\
\hline stan po CC - brak akceptacji próby PSN & 109 & $53,96 \%$ & 153 & $52,40 \%$ & 125 & $\mathbf{4 2 , 8 1 \%}$ \\
\hline stan po CC - uprzednio istniejąca choroba matki & 10 & $4,95 \%$ & 12 & $4,11 \%$ & 30 & $10,27 \%$ \\
\hline stan po CC - niekorzystne prognostycznie warunki do PSN & 9 & $4,46 \%$ & 53 & $18,15 \%$ & 46 & $15,75 \%$ \\
\hline stan po 2 lub więcej cięciech cesarskich & 32 & $15,84 \%$ & 37 & $12,67 \%$ & 45 & $15,41 \%$ \\
\hline stan po CC - zagrażające pęknięcie macicy & 5 & $2,48 \%$ & 15 & $5,14 \%$ & 20 & $6,85 \%$ \\
\hline Uzasadnione wskazania położnicze u pacjentek po CC & 37 & $18,32 \%$ & 22 & $7,53 \%$ & 26 & $8,90 \%$ \\
\hline
\end{tabular}

\section{Dyskusja}

Od wielu lat obserwuje się tendencję do wzrostu odsetka ciąż rozwiązywanych cięciem cesarskim. W Polsce w 2016 r. udział ten wynosił 45,8\%, a w 2017 r. 43,9\%, będąc zarazem jednym z najwyższych w Europie $[1,8]$. W Szpitalu św. Rodziny w Poznaniu odsetek ten kształtował się następująco: 30,1\% w 2016, 32,3\% w 2017 i 34,0\% w 2018 r. Daje to korzystny wynik na tle ogólnopolskim, ale wymaga zauważenia wyraźnej tendencji wzrostowej (Rycina 1). Podjęto więc analizę wskazań do cięć cesarkich w ww. szpitalu i rozważania na temat możliwych przyczyn wzrostu udziału cięć w ogólnej liczbie porodów.

Na podstawie uzyskanych danych ustalono, że w ciągu ostatnich lat udział cięć cesarskich wykonanych po cięciu cesarskim utrzymuje się na podobnym poziomie, tj. między 27\% a 31\% (Tabela 1). W porównaniu do Nowego Szpitala w Wąbrzeźnie (szpital I referencji, dane z lat 2010-2011) wynik ten jest 2-krotnie wyższy [11]. Zaś w porównaniu do uśrednionych danych ze szpitala III referencji - Szpitala Specjalistycznego im. A. Falkiewicza we Wrocławiu (lata 2004-2007) niemal 8-krotnie wyższy, co ciekawe w ogólnym udziale porodów zakończonych drogą brzuszną szpital ten osiągnał wyższe wyniki (43,6\%) niż Szpital św. Rodziny [2]. Może to wynikać w pierwszej kolejności z tego, że w szpitalu I referencji nie powinno się wykonywać ryzykownych operacji położniczych, do jakich należy powtórne cięcie cesarskie. Z drugiej strony ogólna ilość ciąż zakończonych na sali operacyjnej w naszym kraju od roku 2000 do 2016 drastycznie wzrosła - od 19,5\% [2] do niemal 46\%, co musiało wpłynąć też na zwiększenie ilości cięć wykonanych po cięciu cesarskim. Za najważnieszy zaś czynnik należy wziąć pod uwagę, że autorzy niniejszej analizy podają tu całkowitą ilość cięć po cięciu cesarskim, z czego około połowa była uzadaniona innymi wskazaniami położniczymi i pozapołożniczymi. Na rycinie 2 zauważa się wyraźny wzrost udziału cięć cesarskich w ciążach po cięciu z dodatkowymi wskazanimi medycznymi („stan po (C - inne") w ogólnej analizie wskazań do tej operacji. W publikowanych przez innych autorów opracowaniach widoczne są podobne tendencje na przestrzeni ostatnich 10 lat, przez co zformułowano wnioski, że przebycie przez pacjentki cięcia cesarskiego w przeszłości jest główną przyczyną wzrostu odsetka wykonywanych cięć cesarskich obecnie [12]. 
Drugą połowę wskazań do powtórnych cięć cesarskich stanowi brak akceptacji próby porodu drogami natury przez ciężarną. Rekomendacje Polskiego Towarzystwa Ginekologicznego dotyczące cięć cesarskich z roku 2008 warunkują podjęcie próby porodu drogami natury po cięciu podpisaniem przez rodzącą adekwatnej świadomej zgody [5]. Jak można wnioskować z osiągniętych w Szpitalu wyników, jedynie połowa pacjentek aprobuje takie postępowanie. Wynika to z obaw ciężarnych przed powikłaniami [13]. W wieloośrodkowym badaniu Landona i wsp. wykazano, że ryzyko pęknięcia macicy w czasie porodu siłami natury po cięciu cesarskim wynosi $0,7 \%$ oraz nieznacznie wzrasta częstość zapalenia endometrium i encefalopatii niedotlenieniowo-niedokrwiennej noworodka. [14] Możliwość odbycia porodu drogami natury po cięciu dla ciężarnej w ciąży pojedynczej z płodem w położeniu główkowym można łatwo oszacować posiłkując się specjalnymi kalkulatorami dostępnymi online. Przykładowo dla 30-letniej kobiety rasy białej o BMI 30, która nigdy nie rodziła siłami natury, a cięcie cesarskie odbyło się ze wskazań braku postępu porodu, szanse na urodzenie dziecka drogami natury wynoszą $54 \%$. Gdyby pierwsze cięcie cesarskie tej pacjentki odbyło się z innych wskazań - jej szanse na powodzenie próby porodu naturalnego rosną do 69\%. [15] Naturalnie konieczna jest też ocena warunków do odbycia porodu siłami natury przez doświadczonego położnika. Istnieje więc nadzieja, że dzięki edukacji pacjentek uda się w przyszłości ograniczyć ilość powtórnych cięć cesarskich z tego wskazania.

Zgodnie z Rekomendacjami Polskiego Towarzystwa Ginekologicznego dopuszcza się podjęcie próby porodu drogami natury po przebytych 2 cięciach cesarskich [5]. W praktyce w Szpitalu św. Rodziny stan po przebyciu 2 lub więcej cięć cesarskich uznaje się za wskazanie do zakończenia ciąży w drodze elektywnego cięcia cesarskiego. Odsetek cięć z tego wskazania na przestrzeni lat wyniósł od $12,7 \%$ do $15,8 \%$ ogółu cięć cesarskich. Jest to wielokrotnie więcej w porównaniu do szpitala III referenji z lat 20042007 tj. średnio 1,88\%. Wynika to zarówno z ogólnopolskiego trendu wzrostu ilości porodów zakończonych na sali operacyjnej, jak i z dynamicznego rozwoju ginekologii, perinatologii, technik wspomaganego rozrodu oraz innych pokrewnych dziedzin medycyny umożliwijących utrzymanie płodności po przebytych na macicy operacjach.

W latach 2016-2018 najczęstszym wskazaniem do pierwszorazowego cięcia cesarskiego w Szpitalu św. Rodziny były objawy zagrożenia życia płodu (29,6\%-34,5\%). $\mathrm{Na}$ drugim miejscu znalazł się brak postępu porodu (w tym spowodowany nieprawidłowym mechanizmem porodowym), wynosząc od $25,8 \%$ do $28,6 \%$. Z pozostałych przyczyn zakończenia ciąży w warunkach bloku operacyjnego należy wymienić w kolejności ich częstości położenie płodu inne niż główkowe, wskazania ze specjalizacji pozapołożniczych i nagłe stany położnicze. Udział wszystkich wymienionych powyżej wskazań do pierwszorazowego cięcia cesarskiego jest porównywalny w czasie omawianego trzylecia, mało prawdopodobne więc, aby był odpowiedzialny za obserwowany w Szpitalu wzrost odsetka cięć cesarskich w ogólnej liczbie porodów (Rycina 4).
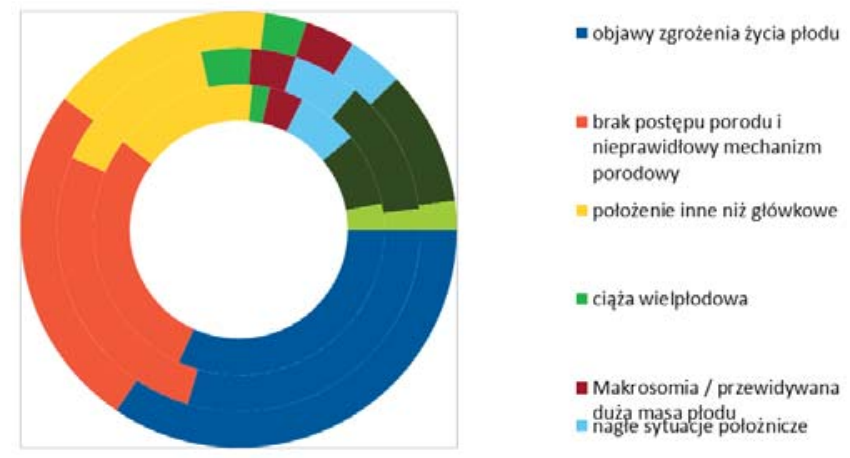

Rycina 4. Rozkład wskazań do pierwszorazowych cięć cesarskich

W danych ze szpitala I referencji z lat 2010-2011 najczęstszymi przyczynami pierwszorazowego cięcia cesarskiego były: brak postępu porodu, niewspółmierność porodowa i zagrażająca zamartwica płodu. W porównaniu z uzyskanymi danymi dużo częściej wskazaniem do cięcia w Nowym Szpitalu w Wąbrzeźnie okazały się brak postępu porodu razem z niewspółmiernością porodową i wysokim prostym staniem główki - razem około $76,5 \%$ w 2010 r. i 50\% w 2011. W omawianej analizie dla ułatwienia wszystkie te wskania zawarto w kategorii brak postępu porodu. Co ciekawe, odnotowany udział wskazań nagłych w obu ośrodkach pokrywa się, wynosząc $6 \%$, zaś wskazań pozapołożniczych jest dwukrotnie większy w Szpitalu Św. Rodziny (średnio 10\%) [11]. Inaczej wygląda porównanie z analizą wskazań do cięć cesarskich w Szpitalu Specjalistycznym im. A. Falkiewicza we Wrocławiu z lat 2004-2007. Tam również najczęstszą przyczyną pierwszorazowego ciecia cesarskiego okazała się zagrażająca zamartwica, jednak dużo rzadziej stawiano rozpoznanie braku postępu porodu $(13,5 \%-16,2 \%)$. Autorzy wrocławskiej analizy zwracają uwagę na nadużywanie wskazań pozapołożniczych do cięć, których udział w ogólnej ilości cięć wykonanych w tym szpitalu wynosił $16,1 \%$ do 20,6\% [2]. Jak wynika z ryciny 3 w Szpitalu św. Rodziny w ciągu ostatnich 3 lat spośród wskazań pozapołożniczych odnotowano wyraźny wzrost ilości pacjentek kierowanych do cięcia cesarskiego z powodu schorzeń ortopedycznych. 
Zauważone różnice między ośrodkami najprawdopodobniej wynikają z ich różnej referencyjności oraz obserwowanej tendencji do zwiększania się odsetka ciąż wysokiego ryzyka, które powinny zostać rozwiązanem cięciem planowym z wskazań okulistycznych, ortopedycznych, nurologicznych i internistycznych [2].

Interesujące jest porównanie danych uzyskanych w poznańskim szpitalu z danymi amerykańskimi z roku 2010. Wynika z nich, że udział cięć cesarkich w ogólnej liczbie porodów wynosił, w zależności od stanu, od 23\% do $40 \%$, w wielu stanach oscylując koło $30 \%$ [16]. Wśród wskazań do pierwszorazowego cięcia najczęściej wymieniano: zatrzymanie postępu porodu (34\%), nieprawidłowy zapis czynności serca płodu (23\%), nieprawidłowe położenie płodu (17\%), ciążę wielopłodową (7\%), wskazania matczyno-płodowe (5\%), makrosomię (4\%) i inne wskazania położnicze (4\%) [17]. Co prawda w Szpitalu Św. Rodziny najczęstszą przyczyną pierwszorazowego cięcia okazały się być objawy zagrożenia życia płodu, niemniej jednak wartości odsetkowe w obu analizach są zbliżone, a w przypadku makrosmii prawie jadnakowe. W związku ze znacznymi różniacami w ilości ciąż zakończonych drogą brzuszną między poszczególnymi stanami USA zasugerowano, że do zwiększania się liczby cięć cesarksich przyczyniają się prawdopodobnie potencjalnie modyfikowalne czynniki, takie jak preferencje pacjentki czy praktyki stosowane w poszczególnych szpitalach. W związku z tym opracowano uzgodnione stanowisko American College of Obstetricians (ACOG) and Gynecologists i Society for Maternal-Fetal Medicine w kwestii bezpiecznego zapobiegania pierwszorazowym cięciom cesarskim [18]. Zaproponowano $w$ nim $m$.in. nowe kryteria diagnostyczne, $w$ tym wydłużone ramy czasowe, dla stwierdzenia braku postępu porodu w I i ll okresie porodu. Zalecono, by w przypadku nieprawidłowości w zapisie KTG w pierwszej kolejności przeprowadzić resuscytację wewnątrzmaciczną, polegającą na zmianie pozycji ciała rodzącej, podaniu tlenu i weryfikacji jej ciśnienia tętniczego. Podkreślono znaczenie stymulacji skóry głowy płodu i amnioinfuzji śródporodowej. Naturalnie w sytuacji braku poprawy zapisu czynności serca płodu należy dążyć do jak najszybszego ukończenia porodu. ACOG proponuję zmianę wartości przewidywanej masy płodu dla podejrzenia makrosomii do $5000 \mathrm{~g}$, a dla ciąż obciążonych cukrzycą do 4500g. Podkreślono też istotność podejmowania próby obrotu zewnętrznego płodów w położeniu niegłówkowym, bezpieczeństwo porodów operacjnych drogą pochwową i celowość ręcznego obrotu główki płodu w przypadku jego nieprawidłowego ułożenia w drugim okresie porodu [19].
Analizując wyniki dotyczące ilości przeprowadzanych porodów operacyjnych drogami natury w Szpitalu Św. Rodziny w latach 2016-2018, zauważono, iż udział procentowy wyżej wymienionych porodów niezmiennie oscyluje w okolicy $5 \%$ ogólnej liczby porodów. Jest to wynik o tyle satysfakcjonujący, że daje poczucie stałej obecności tej metody na sali porodowej naszego szpitala. Bazując na danych z niektórych ośrodków położniczych, pochwowe porody zabiegowe wykonywane są sporadycznie, a ich częstość nie przekracza 1\% wszystkich porodów w ciągu roku [11]. W wielu polskich szpitalach kleszcze i próżnociąg zostały już dawno schowane do lamusa, co znacznie utrudnia edukację młodych lekarzy w przeprowadzaniu tych procedur, co z kolei prognozuje, iż w następnych latach liczba cięć cesarskich będzie wzrastać [2].

Porównując dane Szpitala Świętej Rodziny z 2016 roku z danymi z 2018 roku, stwierdza się tendencję spadkową odsetka przeprowadzanych operacji kleszczowych na korzyść operacji drogą pochwową przy użyciu wyciągacza próżniowego. Królewskie Kolegium Położników i Ginekologów (RCOG, Royal College of Obstetricians and Gynaecologists) zaleca używanie próżnociągu położniczego jako metody z wyboru, a kleszczy wyjściowych w ułożeniach wierzchołkowych [20]. Wybór metody związany jest jednak niewątpliwie z umiejętnościami i doświadczeniem położnika odbierającego poród.

Analizując wskazania do porodów operacyjnych drogą pochwową przeprowadzonych w tutejszym szpitalu w latach 2016-2018, zauważa się, że w wiekszości przypadków (88\%-91\%) na pierwszy plan wysuwa się zagrażająca zamartwica wewnątrzmaciczna, zaś u pozostałych pacjentek - przedłużający się II okres porodu. Uzyskane wyniki były zbliżne do wyników opublikowanych przez Klinikę Położnictwa i Ginekologii Instytutu Centrum Zdrowia Matki Polki w Łodzi w 2007 r. [21].

Porody operacyjne drogą pochwową odgrywają ważną rolę w codziennej praktyce położniczej. Zarówno porody ukończone przy użyciu kleszczy, jak i wyciągacza próżniowego wymagają odpowiednio przeszkolonego personelu, właściwych wskazań, przestrzegania wyznaczonych procedur i rozważenia potencjalnych powikłań. Wilczyński i wsp. stwierdzili jednak, że w każdym przypadku pojawienia się nagłych wskazań do zakończenia porodu przy główce ustalonej w próżni należy przeprowadzić próbę porodu drogami natury celem uniknięcia komplikacji wynikających w trakcie ewentualnego cięcia cesarskiego, gdyż stan urodzeniowy noworodków w obu badanych grupach nie wykazywał zasadniczych różnic statystycznych [22, 23]. W związku z powyższym naszym celem jest kładzenie 
nacisku na szkolenie personelu lekarskiego sali porodowej w zakresie wskazań, prawidłowej oceny warunków, a także techniki przeprowadzania porodów operacyjnych drogą pochwową.

\section{Wnioski}

1. Stwierdza się wyraźną tendencję wzrostową wilości ciąż zakończonych cięciem cesarskim w Szpitalu św. Rodziny w Poznaniu w latach 2016-2018.

2. Analogicznie do wzrostu udziału cięć cesarskich w ogólnej liczbie porodów w szpitalu obserwuje się wzrost ilości cięć cesarskich u pacjentek z przynajmniej 1 cięciem w wywiadzie i dodatkowymi wskazaniami medycznymi.

3. Odsetek porodów operacyjnych drogą pchwową utrzymuje się na wzglęgnie stałym poziomie w badanym przedziale czasu.

4. W grupie ciąż zakończonych operacyjnie drogą pochwową wyraźnie częściej stosowano kleszcze położnicze, niemniej jednak udział ciąż zakończonych wyciągaczem próżniowym stopniowo rośnie.

\section{Oświadczenia}

\section{Oświadczenie dotyczące konfliktu interesów}

Autorzy deklarują brak konfliktu interesów.

190

\section{Źródła finansowania}

Autorzy deklarują brak źródeł finansowania.

\section{Piśmiennictwo}

1. Nowacki R, Pańszczyk M. Cięcie cesarskie, aktualne tendencje. Spojrzenie z perspektywy prywatnego szpitala położniczego; Perinatologia, Neonatolgi i Ginekologia, Tom 1, zeszyt 1, 4850,2008

2. Wilczyńska M, Różańska-Kohsek A, Bielanów T. Analiza wskazań do cięć cesarskich w Szpitalu Specjalistycznym im. A. Falkiewicza we Wrocławiu w latach 2004-2007i rozważania nad przyczyną ich wzrostu. Perinatologia, Neonatologia i Ginekologia, tom 1, zeszyt 1, 27-31, 2008.

3. Bręborowicz GH (red.). Położnictwo i ginekologia, PZWL, Warszawa 2018, tom 1, 438-450.

4. Karwan-Płońska A. Analiza wskazań do cięcia cesarskiego. Nowa Medycyna - Ginekologia (8); 32-4, 2000.

5. Rekomendacje Polskiego Towarzystwa Ginekologicznego, Cięcie cesarskie, 2008.

6. Poręba R, Jędrzejko M, Poręba A, Sioma-Markowska U. Wskazania do cięcia cesarskiego, Perinatologia, Neonatolgi i Ginekologia, Tom 1, zeszyt 1, 11-18, 2008.

7. Autor: jp/sk / Źródło: tvn24.pl (http://www.tvn24.pl), https://www.tvn24.pl/wiadomosci-z-kraju,3/cesarskie-cieciaw-polsce-1999-2015-stanowisko-ministra-zdrowia,729371. html, dostęp na dzień 22.02.2018.

8. Solecka M, Kurier MP. W niechlubnej czołówce, 13.02.2019 www.mp.pl/pacjent/ciaza/aktualnosci/204026,w-niechlubnej-czolowce.

9. WHO, HRP, WHO statement on caesarean section rates, 1-4, kwiecień 2015.
10. Dziennik Ustaw Rzeczypospolitej Polskiej; Rozporządzenie Ministra Zdrowia z dnia 16 sierpnia 2018r. W sprawie standardu organizacyjnego opieki okołoporodowej. Pkt 6 .

11. Waleśkiewicz-Ogórek K, Rajewski P, Kolesińska-Konkel $1 \mathrm{~N}$ i wsp. Analiza wskazań do cięcia cesarskiego w Nowym Szpitalu w Wąbrzeźnie; Forum Medycyny Rodzinnej 2013, tom 7, nr 6, 295-299.

12. Stasiełuk A, Langowicz I, Kosińska-Kaczyńska K, Pietrzak B, Wilgoś M. Czy epiedmia cięć cesarskich jest wykładnikiem liberalizacji wskazań?. Ginekologia Polska Nr 8, 604-608, 2012.

13. Roztocka A. Powikłania po cięciu cesarskim, Perinatologia, Neonatologia i Ginekologia, tom 7, zeszyt 3, 154-164, 2014.

14. Landon MB, Hauth JC, Leveno KJ i wsp. National Institute of Child Health and Human Development Maternal-Fetal Medicine Units Network. Maternal and perinatal outcomes associated with a trial of labor after prior cesarean delivery. $\mathrm{N}$. Engl. J. Med. 351(25): 2581, 2004.

15. Strona internetowa National Institute of Child Health and Human Development Maternal-Fetal Medicine Units Network https://mfmunetwork.bsc.gwu.edu/PublicBSC/MFMU/ VGBirthCalc/vagbirth.html dostęp na 20.02.2019.

16. Martin JA, Hamilton BE, Ventura SJ i wsp. Births: final data for 2011. Natl. Vital Stat. Rep., 2013; 62: 1-90.

17. Barber EL, Lundsberg LS, Belanger K i wsp. Indications contributing to the increasing cesarean delivery rate. Obstet. Gynecol., 2011; 118: 29-38.

18. Uzgodnione stanowisko American College of Obstetricians and Gynecologists i Society for Maternal-Fetal Medicine, Wskazania do pierwszorazowego cięcia cesarskiego, z dnia 20.10.2015, https://www.mp.pl/ginekologia/ poloznictwo/120410,wskazania-do-pierwszorazowego-ciecia-cesarskiego dostęp na 18.02.2019.

19. Uzgodnione stanowisko American College of Obstetricians and Gynecologists i Society for Maternal-Fetal Medicine, Wskazania do pierwszorazowego cięcia cesarskiego, z dnia 20.10.2015, https://www.mp.pl/ginekologia/ poloznictwo/120414, postepowanie-kliniczne dostęp na 18.02.2019.

20. Royal College of Obstetricians and Gynaecologists. Effective procedures in obstetrics: Suitable Audit. National Audit Unit, Manchester 1993.

21. Brocka-Zakrzewska U, Pietrzak Z, Sobantka S i wsp. Poród kleszczowy. Analiza doświadczeń własnych z Kliniki Położnictwa i Ginekologii ICZMP w latach 2002-2004. Kliniczna Perinatologia i Ginekologia, tom 43, zeszyt 4, 32-35, 2007.

22. ACOG; When is the right time for operative vaginal delivery? Contemporary Ob./Gyn Vol. 50 No 4, April 2005.

23. Wilczyński A, Krzemieniowska J, Gryboś M i wsp. Kleszcze średnie czy cięcie cesarskie? Gin.Pol.; 1(supl.2): 163-172, 2006.

Zaakceptowano do edycji: 20.08.19 Zaakceptowano do publikacji: 26.09.19

Adres do korespondencji:

Magdalena Szumska

ul. Grunwaldzka 167B/18

60-322 Poznań

Martyna Kozłowska-Wytyk

ul. Gruszowa 11

62-006 Bogucien 